\title{
Algajate õppejõudude õpetamisarusaamad fotointervjuude põhjal
}

\author{
Mari Karm ${ }^{\text {al }}$, Marvi Remmik ${ }^{\mathrm{a}}$ \\ a Tartu Ülikooli haridusteaduste instituut
}

\begin{abstract}
Annotatsioon
Esimesed tööaastad on õppejõu professionaalsuse kujunemise seisukohast väga tähtsad, sest siis pannakse alus õppejõu identiteedi kujunemisele, liitutakse ülikooli kogukonnaga ning võetakse omaks selles valitsevad väärtused ja traditsioonid või vastandutakse neile, samuti arenevad sel ajal õpetamisoskused.

Varasemad uurimused on näidanud, et õppejõudude arusaamade, uskumuste ja väärtuste uurimine on keeruline, sest sageli pole õppejõud teadvustanud, millistele arusaamadele ja uskumustele nende professionaalne praktika toetub. Samas on visuaalsed uurimismeetodid andnud häid võimalusi õppejõu õpetamisarusaamade, professionaalse identiteedi ja selle erinevate aspektide, elukogemuste ja mälestuste tähenduse ning isiklike teooriate uurimiseks, sest need võimaldavad intervjueeritavale anda impulsi oma arusaamade teadvustamiseks ja sõnastamiseks.

Artiklis analüüsitakse 13 algaja õppejõu õpetamisarusaamu ja nende kujunemist fotointervjuude põhjal. Analüüsi tulemusel leiti, et algajat õppejõudu kui rühma ei või käsitleda lihtsustatult, sest nad on erinevad. Algajate õppejõudude õpetamisarusaamad ei ole veel välja kujunenud ning seetôttu otsivad õppejõud alles endale sobivamat ja arusaamadega kooskõlas olevat õpetamisviisi. Uurimuse tulemused osutasid, et algaja õppejõu õpetamisarusaamade kujunemisel on peamine roll õppejõu enda õppimiskogemusel üliõpilasena ning sellel, milline on tema arusaam õppimisest. Uurimus näitas, et algaja õppejõu õpetamisarusaamad peegeldavad ka seda, millise õppejõuna soovitakse ennast näha olevikus ja millises suunas areneda tulevikus. Algajate õppejõudude erinevuste mõistmine võimaldab ülikoolidel välja arendada tugisüsteeme õppejõudude professionaalse õppimise toetamiseks. Kuna õppejõud on erinevad, siis vajavad nad ka erinevat toetust.
\end{abstract}

Võtmesõnad: algaja õppejõud, õpetamisarusaamad, fotointervjuu, ülikooliharidus

$\overline{1}$ Haridusteaduste instituut, sotsiaal- ja haridusteaduskond, Tartu Ülikool, Salme 1a, 50103 Tartu,mari.karm@ut.ee 


\section{Sissejuhatus}

Ülikool on muutumises ning järjest mitmekesisemaks on muutunud ülesanded, mida ülikooli õppejõul tuleb täita. Erinev on inimeste teekond ülikooli (otse pärast ülikooliõpinguid, praktikast), töösuhted ülikooliga (palju osalise tööajaga õppejõude), rahastamisviisid (projektipõhine rahastamine) - kõik see mõjutab omakorda ülikooli õppejõu töö iseloomu (Debowski, 2012; Fanghanel, 2012; Malcolm \& Zukas, 2009; Whitchurch, 2012).

Õppejõudude töös põimuvad akadeemilised ja mitteakadeemilised ülesanded: uurimistöö, õpetamine, projektikirjutamine ja -administreerimine, õppekava juhtimine, akadeemilise struktuuriüksuse juhtimine (Whitchurch, 2012). Iga õppejõud käsitleb ja tõlgendab akadeemilise töö tahke ja rolle erinevalt ning siin määravad rõhuasetuse õppejõu personaalne võimekus ja eelistused ning organisatsiooni kontekst (Debowski, 2012). Järjest enam õppejõude tajub konflikti kõrgkoolide poolt õppejõule suunatud ootuste ja samas kesise institutsionaalse toetuse vahel (Billot, 2010). Seetõttu leiab Vardi (2011), et üks olulisemaid küsimusi kõrghariduse ees on, kuidas saavutada, et õppejõud ja ülikoolid suhtuksid õpetamisse sama tõsiselt kui uurimistöösse, kuidas tunnustada hästi õpetavaid õppejõude ning kaasata uusi õppejõude ülikoolide töösse.

Muutused ülikoolis ja õppejõu tegevustes toovad kaasa, et alustavalt õppejõult oodatakse juba oma karjääri alguses toimetulekut mitmete ülesannetega, sealhulgas õpetamisega. Seepärast on oluline uurida ja mõista, kuidas algaja õppejõud mõtestab oma tegevust ülikoolis, millistel õpetamisarusaamadel tema tegevus põhineb ning kas ja kuidas ta ennast õppejõuna arendab.

\section{Teoreetiline ülevaade}

\section{Teadustöö ja õpetamise seosed}

Õppejõu professionaalses tegevuses on oluline õppejõu kui teadlase ja õppejõu kui õpetaja roll. Kuigi õppejõududel on oma igapäevases tegevuses reaalselt üsna võimatu eristada teadlase ja õpetaja identiteeti (Malcolm \& Zukas, 2009), näitavad uurimused (Billot, 2010; Norton, Aiyegbayo, Harrington, Elander, \& Reddy, 2010), et õppejõudude jaoks on keerukas võrdselt hästi tegeleda uurimistöö, üliõpilaste õpetamise ja oma valdkonna praktikaga ning õpetamine, administreerimine ja uurimistöö võivad sattuda üksteisega konflikti. Kui teadustegevus on ülikoolis formaalselt rohkem väärtustatud, siis määratlevad õppejõud ennast pigem teadlasena ning neil on keerulisem omaks võtta õpetaja identiteeti (Åkerlind \& McAlpine, 2010). 
Sageli keskendutakse õppejõu professionaalset arengut puudutavates uurimustes kas õppejõu kui õpetaja või kui teadlase tegevusele, vaadeldes nende kujunemist ja arengut teineteisest sõltumatult (Åkerlind, 2008). Samas võimaldab just teadustöö ja õpetamise seostamine edendada nii ülikooliõpet kui ka teadustööd. Uurimused (Coate, Barnett, \& Williams, 2001; Robertson \& Bond, 2001) viitavad, et teadustöö võib kaasa aidata õpetamise tõhustamisele, sest teadlased lähtuvad õpetades pigem isiklikest uurimiskogemustest, mitte kaudsetest allikatest. Teadustöö ja õpetamise lõimimine võimaldab üliõpilastel paremini omandada uurimistöö oskusi, mis on vajalikud tänapäevases teadmistepõhises maailmas toimetulekuks (Brew, 2010; Elen, Lindblom-Ylänne, \& Clement, 2007).

Õppejõud peavad läbi mõtlema, mida nad käsitavad õpetamise ja uurimistööna ning kuidas nad mõistavad õppimist enda kui õppejõu ja oma üliõpilaste vaatenurgast (Brew, 2010). Elen jt (2007) rõhutavad oma uurimuses, et õppejõud mõtestavad õppimist ja teadmise kujunemist teadustöö ja õpetamise kontekstis erinevalt. Teadustöö kontekstis mõistetakse õppimist ja teadmist kui midagi, mida jagatakse teistega ja mille üle arutletakse, ent õpetamise kontekstis nähakse seda pigem üliõpilaste individuaalse tegevusena.

Ehkki õppejõu õpetaja ja teadlase identiteeti on ülikoolides kujundatud teineteisest lahus ning teadustöösse panustamist hinnatud heast õpetamisest enam, on olukord siiski muutumas ning järjest rohkem väärtustatakse ka head õpetamist.

\section{Õpetamisarusaamad}

Ülikooli õppejõu õpetamistegevuses on tähtis koht tema õpetamisarusaamadel. Uurimused näitavad, et õppejõudude õpetamisarusaamad mõjutavad nende õpetamispraktikat (Trigwell \& Prosser, 1996). Sellest, millise õpetamisviisi esindajana end määratletakse, oleneb ka see, kuidas kavatsetakse oma õpetamispraktikat arendada. Kember (1997) toob välja, et üldiselt saab õpetamisarusaamad paigutada kahe põhikontseptsiooni teljele: õppejõukesksed (teacher-centred) arusaamad keskenduvad aine sisu või teadmiste edasiandmisele ning üliõpilasekesksed (student-centred) üliõpilaste õppimise toetamisele.

Mitmed edasised õpetamisarusaamade uurimused toetuvad üldjoontes Kemberi (1997) tõlgendusele, täiendades või täpsustades seda. Van Driel, Verloop, van Werven ja Dekkers (1997) lisavad eespool nimetatute suhtes keskel asuva kontseptsiooni, mida nad nimetavad üliõpilast juhtivaks (studentdirecting). Üliõpilast juhtivale arusaamale iseloomulik joon on intensiivne suhtlus õppejõu ja üliõpilaste vahel. Õppejõud juhib protsessi aktiivselt, 
pöörates tähelepanu üliõpilase õppimisele ja pakkudes talle võimalusi (lisa) konsultatsioonideks ning andes õppimise kohta tagasisidet. Üliõpilast juhtiv arusaam ei ole õppejõukeskne, sest peetakse oluliseks üliõpilaste aktiivset osalemist, ent see ei ole siiski ka üliõpilasekeskne, sest õppejõud kontrollib protsessi ning keskendub materjali läbivõtmisele.

Åkerlind (2004) eristab õpetamisarusaamades nelja kategooriat, käsitledes õpetamisena 1) info edastamist, 2) heade suhete loomist (oluline on nii üliõpilaste rahulolu kui ka sisu edastamine), 3) üliõpilaste kaasamist (tagada, et üliõpilased oleksid entusiastlikud ja motiveeritud) ning 4) üliõpilaste õppimise toetamist (julgustada üliõpilasi analüüsivalt ja loovalt mõtlema). Seega on Åkerlind (2004) õpetamisarusaamu süstematiseerides sarnasel seisukohal kui van Driel jt (1997) ning eristab selgelt arusaama, mille esindajad väärtustavad üliõpilastega suhtlemist ja nende kaasamist.

Analüüsides õppejõudude õpetamiskirjeldusi, leiavad Postareff ja Lindblom-Ylänne (2008), et need jagunevad sisukeskse (content-focused) ja õppimiskeskse (learning-focused) arusaama vahel. Nende kahe arusaama eristamise aluseks on erinevus õpetamise eesmärgis. Sisukeskse käsitluse puhul on selleks teadmise edasiandmine ja õppimiskeskse käsitluse puhul üliõpilaste õppimise toetamine. Nende kahe kontseptsiooni erinevused avalduvad järgmistes valdkondades: õpetamisprotsessis (sh õppe kavandamine, õpetamine, hindamine), õpikeskkonna kujundamises (sh õpetaja ja üliõpilase rollid, interaktsioon, atmosfäär), õppimisarusaamades ning õpetamisalases arengus (õpetamisoskuste areng, pedagoogiline teadlikkus). Mitmetes uurimustes tuuakse esile õpetamisarusaamade avaldumise erinevaid valdkondi, nt Gonzáles (2011) eristab üliõpilaste motivatsiooni toetamist, Åkerlind (2004) õpetamise tähendust ja tähtsust õppejõule endale.

Opetamisarusaamade puhul on uurijad erineval arvamusel selles, kas arusaamad on iseseisvad või seostatud. Õpetamiskontseptsioonid paigutuvad Åkerlindi (2004) kohaselt seostatult ja hierarhiliselt, mis tähendab, et õppimiskeskse õppejõu arusaamades sisalduvad sisu edastamise ja/või heade suhete kujundamise aspektid, ent mitte vastupidi. Õpetamisarusaamu analüüsides pööratakse tähelepanu ka sellele, kuivõrd need on püsivad või muutumises ning milline on muutuste suund. Varasemad uurimused (Kugel, 1993; Sherman, Armistead, Fowler, Barksdale, \& Reif, 1987) näitavad, et tööd alustades on õppejõudude arusaamad pigem õpetamiskesksed ning õpetamiskogemuste kasvades ja koolituste tulemusena toimub muutus õppimiskesksuse suunas. Teisalt osutavad uurimused (Norton, Richardson, Hartley, Newstead, \& Mayes, 2005; Remmik \& Karm, 2013), et algajad võivad asuda õpetamiskeskse-õppimiskeskse arusaama teljel erinevates kohtades ning olenevalt asjaoludest (isiklikud kogemused, koolitused, kogukonna 
traditsioonid, üliõpilaste tagasiside) võivad muutused toimuda kas õpetamiskesksuse või õppimiskesksuse suunas.

Õpetamisarusaamad ei pruugi alati väljenduda õpetamispraktikas ning sageli vaheldatakse nii õppimis- kui ka sisukeskseid lähenemisi (GuzmánValenzuela, 2013; Lindblom-Ylänne, Trigwell, Nevgi, \& Ashwin, 2006). Uurimistulemused (Eley, 2006) näitavad, et õppejõud ei ole teadlikud oma õpetamisarusaamadest ning pole selge, kuivõrd nad reaalses õpetamisprotsessis planeerimisotsuseid ja valikuid tehes oma arusaamadest juhinduvad.

Prosser, Martin, Trigwell, Ramsden ja Middleton (2008) toovad välja seosed selle vahel, kuidas õppejõud saavad aru uurimistööst ja oma valdkonnast ning kuidas nad mõistavad õpetamist. Kui õppejõud mõistab oma valdkonna sisu kui üksikute faktide kogumit ning uurimistööd kui üksikute uurimisprojektide tegemist, siis on tal tõenäolisemalt õppejõukeskne arusaam. Kui õppejõud käsitab uurimistööd kui tervikut (rõhutatakse valdkonna kontseptuaalset mõistmist ja arengut), siis läheneb ta õpetamisele pigem üliõpilasekeskselt, taotledes üliõpilase õppimise puhul mõistmist ja arusaamade muutumist.

\section{Ettekujutus endast õppejõuna ja oma õpetamise arendamine}

Õppejõu õpetamisarusaamad mõjutavad ka seda, millisena ta näeb enda arengut õppejõuna. Õppejõuks kujunemisele avaldavad suurt mõju doktoriõpingud, mille käigus doktorantidel kujuneb ettekujutus õppejõu identiteedist ning enda tõekspidamistest ja tõhususest: nad kõrvutavad oma arusaamu ja ootusi ülikooli või oma valdkonna väärtustega ning hindavad tulevase karjääri võimalusi (McAlpine \& Amundsen, 2009).

McAlpine ja Weston (2000) osutavad, et ópetamiskontseptsioonidel on oluline osa selles, milliseid muutusi õppejõud oma õpetamispraktikas on valmis tegema. Kui õppejõud on õpetamiskeskse arusaamaga, siis ta võib küll reflekteerida oma õpetamist ja kavandada muutusi, kuid need muutused jäävad sageli õpetamiskeskse arusaama raamidesse (nt veel rohkem materjali, veel paremad loengud).

Åkerlind (2003) näitab oma uurimuses, et õpetamiskeskse arusaamaga õppejõud keskendub oma õpetamistegevuse arendamisel rohkem aine sisule, et saavutada suurem kindlus õpetamisel. Kui õppejõud peab oluliseks üliõpilaste kaasamist, siis pöörab ta tähelepanu õpetamisoskuste arendamisele ja õpetamismeetodite omandamisele. Kui õppejõule on omane õppimiskeskne arusaam, siis ta arendab ennast eesmärgiga leida võimalusi, kuidas toetada üliõpilaste õppimist (nt tagasiside kogumine ja analüüs). 
Postareff ja Lindblom-Ylänne (2008) toovad välja, et õppejõudude arusaamad enda arendamisest õppejõuna olenevad sellest, kas nad on rohkem sisu- või õppimiskeskse arusaamaga. Õppimiskeskse arusaamaga õppejõud märkavad enda praktikas tegevusi, mis vajavad arendamist, ning neil on huvi saada õppejõuna paremaks (nt osalevad pedagoogilistel kursustel). Sisukeskse arusaamaga õppejõudude puhul näitavad uurimistulemused, et õppejõud ei teadvusta oma arenguvaldkondi ning ei tee pingutusi oma õpetamistegevuse arendamiseks.

Uurimused osutavad, et algaja õppejõud võib sattuda vastukäivate ootuste ja nõudmiste keskele, mis omakorda võivad olla vastuolus tema enda seniste kogemuste ja tõekspidamistega. Seetõttu on oluline välja selgitada, kuidas algaja õppejõud mõtestab oma tegevust ülikoolis, millistel õpetamisarusaamadel tema tegevus põhineb ning kuidas ta ennast õppejõuna arendab. Uurimuse eesmärkide põhjal püstitati järgmised uurimisküsimused:

1) kuidas algajad õppejõud kirjeldavad oma tööd ülikoolis?

2) kuidas algajad õppejõud kirjeldavad oma õpetamisarusaamu?

3) millisena kujutlevad algajad õppejõud oma arengut õppejõuna?

\section{Metoodika}

See artikkel on osa algaja õppejõu professionaalsuse kujunemise suuremast uurimusest, millesse oli kaasatud 43 õppejõudu. Uurimuse esimeses etapis viidi algajate õppejõududega läbi eluloolised intervjuud. Artikkel põhineb fotointervjuul 13 õppejõuga, kellega olid enne tehtud eluloointervjuud. Algaja õppejõuna on uurimuses määratletud õppejõud, kel on õpetamiskogemust 1-6 semestrit. Intervjueeritud õppejõud töötasid ülikoolis erinevatel akadeemilistel ametikohtadel, nt assistentide, lektorite, teadurite, projektijuhtide ja peaspetsialistidena, kes muude töökohustuste hulgas õpetasid mõnda ainekursust.

Uurimismeetodina kasutati fotointervjuud. Fotointervjuu (photo-elicitation, photo-interview) (Hurworth, 2003; Taylor, 2002) puhul kasutatakse fotosid intervjuu käivitamiseks, fotode abil saab ärgitada arutelu, samuti aitavad need püsida uuritaval teemal. Fotod annavad intervjueeritavatele impulsi oma arusaamade esiletoomiseks ja sõnastamiseks ning fotod kui visuaalsed kujundid võimaldavad pakkuda ka teist laadi informatsiooni (Harper, 2002; Rose, 2007).

Fotointervjuud ajendas kasutama asjaolu, et visuaalsed uurimismeetodid, sh fotointervjuud, on andnud häid tulemusi õpetamisarusaamade uurimisel (Nevgi \& Löfström, 2013; Taylor, 2002; Weber \& Mitchell, 1996; 
Woodley-Baker, 2009). Põhjusena tuuakse välja, et ideaale, arusaamu ja uskumusi on raske uurida, sest inimesed pole sageli selgelt teadvustanud, millistel arusaamadel nende õpetamispraktika põhineb (Taylor, 2002). Fotointervjuu aitab kaasa usalduse tekkimisele ning toetab uurimuse usaldusväärsust meetodite triangulatsiooni kaudu (Hurworth, 2003; Taylor, 2002).

Fotointervjuuks paluti leida või teha fotosid, et saada vastus järgmistele küsimustele: „Milline on Teie kujutlus õppimisest?”, „Milline on Teie kujutlus õpetamisest?”, „Kuidas kujutlete ülikooli õppejõudu?”, „Millise õppejõuna kujutlete ennast tulevikus?". Osalejad võisid teha uusi fotosid, otsida fotosid oma kogudest või joonistada pildi, kui sobivat fotot ei õnnestunud leida.

Fotointervjuudes osalenud õppejõud olid järgmistest valdkondadest: humaniora $(\mathrm{n}=2)$, socialia $(\mathrm{n}=6)$ ja realia et naturalia $(\mathrm{n}=5)$. Fotointervjuudes osalenud õppejõududest 10 õppis samal ajal doktoriõppes ning 3 tegi erialast praktilist tööd väljaspool ülikooli.

Fotode analüüsimisel kasutati kaudset analüüsi (Taylor, 2002), mis seisnes selles, et osalenud õppejõud tõlgendasid intervjuu käigus ise fotodel leiduvaid kujundeid. Uurijatena analüüsisid artikli autorid algajate õppejõudude intervjuudes väljendatud tõlgendusi ja selgitusi, fotosid ei ole analüüsitud eraldi. Intervjuude analüüsimiseks kasutati temaatilist analüüsi (Ryan \& Bernard, 2003) ning analüüsi viisid läbi mõlemad artikli autorid sõltumatult. Kui autorite vahel esines kodeerimisel või kategoriseerimisel ebakõla, siis mindi tagasi originaalandmete juurde ning arutleti tulemuste üle seni, kuni saavutati konsensus. Kuigi fotointervjuudes olid intervjueeritavatele ette antud konkreetsed küsimused, mille kohta nad olid otsinud sobiva foto, siis vastustes räägiti kõigest korraga, mistõttu tuli kõigepealt leida põhiteemad. Seejärel kodeeriti materjal põhiteemade kaupa ning kujunesid järgmised kategooriad: õpetamise ja teadustöö suhted (seosed, uurimistöö roll õpetamisel), õpetamisarusaamad (tegevused, rollid, tagasiside õppimise kohta, õhkkonna loomine, suhted üliõpilastega), kuulumine kogukonda, valmisolek ennast arendada, arendamisvaldkonnad ja -suunad. Analüüsi lõppjärgus koostati võrdlustabel, et kõrvutada erinevate fotointervjuude materjale ning leida läbivaid teemasid ja juhtumiüleseid mustreid.

Kuna lood sünnivad intervjueerija ja intervjueeritava koostöös, siis tuleb arvestada, mis kontekstis nad on tekkinud (Erkkilä \& Mäkelä, 2002; Kvale, 2006). Cortazzi ja Jini (2006) järgi on intervjuude puhul oluline tegur uurija identiteet, mis mõjutab jutustaja valikuid, kellele, millal, kus, miks ja milliseid lugusid rääkida. Samuti mõjutab uurija isik seda, kuidas materjali analüüsitakse ning milline mõju võib tal olla materjali kogumisele ja analüüsimisele. Käesolevas uurimuses on intervjueerijad ja intervjueeritavad pärit samast keskkonnast (ülikoolist) ning intervjuu toimus kolleegide vestlusena. Mõned 
intervjueeritavad olid kohtunud õpetamiskursuse käigus (intervjueerija oli olnud koolitaja rollis). Ühelt poolt võimaldas see osutada ühistele kogemustele, teisalt võis lisada teatud ebavõrdsust (koolitaja-õppija suhe).

Tsiteeritud intervjuukatkeid on parema mõistetavuse huvides toimetatud: vähendatud on täitesõnade hulka ja kordusi.

\section{Tulemused}

Fotode otsimise protsess ja selle kirjeldamine kajastasid intervjueeritavate kaasatust uurimisprotsessi. Fotosid otsiti olemasolevate hulgast, ent samuti pildistati spetsiaalselt fotointervjuu jaoks. Fotode tegemine võis olla kavandatud selge kontseptsiooniga (nt Tartus asuvad skulptuurid).

Ma alguses mõtlesin küll, et äkki ma saan tekitada mingi teema või siis mingisuguse terviku läbi mingite kujude, mis Tartus nagu haakuks nende teemadega. Lotmani pildistasin õppimise teema juurde. Minu arusaam õppejõust, ma tahtsin Kristjan Jaaku minna pildistama, et see tundus ... See isa ja poeg on sümbolina minu arust väga kena. Tartus selliseid kujusid leiaks, aga jah Kalevipoeg on liiga selline heroiline. Ma nii maskuliinsena ennast ei tunne õppejõuna. (Humaniora, 16A)

Fotode otsimise kirjeldused on kooskõlas varasemate uurijate tähelepanekutega, et fotointervjuud suunavad osalejaid pikema aja vältel ja sügavamalt teema üle mõtlema (Taylor, 2002). Fotod võisid olla valitud konkreetse sõnalise kujundi peegelduseks (tee, puu, prohvet, kummut, udu, teeviit), ent neid võidi kasutada ka meeleolu väljendamiseks (õppejõud kui meelerahu seisund) või tegevuste ilmestamiseks. Mitmed intervjueeritavad kasutasid võimalust joonistada oma ideed kõige täpsemalt väljendav pilt. Sõltumata küsimusest räägiti läbisegi õppimisest, õpetamisest ja õppejõuks olemisest. Nii mõnigi kord oli valitud sama pilt vastuseks erinevatele küsimustele (nt võis olla sama foto õppimise ja õpetamise või õpetamise ja õppejõu kohta).

Intervjuude analüüsimisel võis märgata, et vastajad vahetasid intervjuu käigus vaatepunkti: osale intervjuuküsimustest vastati õppejõu vaatepunktist, osale üliõpilase vaatepunktist, kirjeldades pigem seda, mida nad üliõpilasena ootavad õppejõult, mitte niivõrd seda, mida nad ise õppejõuna teevad või teeksid. Põhjus võib olla selles, et mitmed intervjueeritavad õpivad õppejõutöö kõrvalt ka doktorantuuris. 


\section{Teadustöö ja õpetamise seosed}

Õppejõutöö erinevaid rolle kajastavates uurimustes (Åkerlind, 2008; Reybold, 2005) tuuakse sageli välja selle töö kaks tahku - teadlane ja õpetaja - ning vastuolud nende rollide täitmisel. Intervjueeritud õppejõud arutlesid samuti oma teadustöö ja õpetamise suhete üle. Mõned intervjueeritud tõid selgesti esile, et nende jaoks on peamine õpetamine. Nad hindasid oma õpetamisoskusi tugevamaks ning nägid enda missiooni heas õpetamises eesmärgiga aidata kaasa ülikooli õpetamiskvaliteedi parandamisele.

Viimasel ajal olen ma palju rohkem jõudu ja aega pühendanud just õpetamise küsimustele. Sellepärast, et ma tunnen, et on väga suuri vajakajäämisi, et see on see koht, kus ma saan reaalselt midagi ära teha. (Realia et naturalia, 31A)

Samuti võis õpetamisele pühendumise taustaks olla tõdemus, et enda kui teadlase oskuste suhtes ollakse ebakindlamad. See annab kinnitust seisukohale (Boyd \& Harris, 2010), et professionaalne identiteet on seotud kompetentsustundega ning algaja õppejõud seostab ennast pigem valdkonnaga, kus ta tunneb end kindlamalt ja kogeb suuremat rahulolu.

Muidugi ma tahaksin saavutada ka teadusmaailmas mingisuguseid tulemusi, aga see on jälle see mugavuse asi, selle õpetamise ja nende probleemidega olen ma nüüd järjest rohkem kokku puutunud ja ma tunnen, et mul on selline teadmiste tase, et ma tunnen ennast seal natuke kodusemalt. Ja see teadusmaailm on jälle selline kaardistamata ala, kuhu peab sisse murdma ja palju tööd tegema. (Realia et naturalia, 31A)

Üllatav oli fotointervjuudes kajastuv noorte õppejõudude teatav muretus teadussaavutuste ja publikatsioonide suhtes. Põhjuseks võib pidada intervjuuküsimuste (küsimuste keskmes on õpetamine) või valimi eripära (enamik vastanutest on ise alles doktorandid ning seetõttu ei pea nad iseseisva uurijana taotlema teadusrahasid ega publitseerima).

Mitmed intervjueeritud õppejõud rõhutasid, et just teadusega tegelemine teeb ülikoolis töötamise huvitavaks, ning olid veendunud, et uurimistöö loob aluse õppejõu professionaalsusele ja aitab ka õpetamist põnevamaks muuta. Nad tõid välja, et õppejõul on võimalik oma uurimistöö tulemusi kasutada ainete õpetamisel. Intervjueeritud õppejõud leidsid, et nii teadlase kui ka õpetaja roll on olulised ning täiendavad teineteist, nt uurimistööga tegelemine ja artiklite kirjutamise kogemus on abiks üliõpilastööde juhendamisel ja üliõpilaste suunamisel. 
Mitmed intervjueeritud õppejõud osutasid, et õppejõutöö kaks poolt uurimistöö ja õpetamine - teevad selle töö meeldivaks.

Õppejõud tegelikult ma ei saakski olla, kui ma neid artikleid ei kirjutaks. Mul jääks ju tegelikult ka oluline osa koolitustest saamata, näiteks konverentsidel käimised, kui ma ei kirjutaks artikleid. See on ühe töö kaks poolt, igatahes minul on väga hea meel, et on see võimalus käia konverentsidel ja kirjutada artikleid. (Socialia, 13A)

Uurimistööga tegelemist nägid noored õppejõud kui vaimset pingutust nõudvat tegevust, mis võimaldab säilitada sära ja huvi oma töö vastu. Kuigi otsest küsimust fotointervjuudes teadustöö kohta ei olnud, rääkisid intervjueeritavad üsna palju teadustöö ja õpetamise ning teadustöö ja eraelu vahelise tasakaalu leidmisest ning teadustöö kasutamisest õpetamisel. Ka mitmed valitud fotod olid seotud teadustööga (nt esimene poster, juhendamissituatsioon). Intervjueeritud õppejõud nägid õpetamise ja teadustöö seostamises hea õpetamise eeldust, millele osutavad ka selle valdkonna uurimused (Brew, 2010; Coate et al., 2001; Robertson \& Bond, 2001).

\section{Õpetamisarusaamad}

Õppejõudude õpetamisarusaamades väljenduvad nende kavatsused ja tõekspidamised, kuidas olla õpetamispraktikas edukas. Mitmed intervjueeritud õppejõud kirjeldasid õpetamist viisil, mis peegeldab õppimiskeskset arusaama. Nende õppejõudude jaoks oli oluline saada üliõpilane õppima ning nad otsisid selleks sobivaid õppemeetodeid ja töövõtteid. Ka Warhursti (2008) uurimus näitab, et kui õppejõud olid omaks võtnud õpetamise aspekti oma professionaalses identiteedis, siis osutas see suuremale tõenäosusele, et nad rakendavad õppimiskeskset õpetamist. Mitmed uurijad (Åkerlind, 2003; McAlpine, Amundsen, Clement, \& Light, 2009) on leidnud, et õpetamispraktika algul on algajad õppejõud enamasti mures aine sisu pärast, kogemuse kasvades pööratakse enam tähelepanu õpetamismeetoditele ning sobilike õpetamisstrateegiate leidmise järel saab oluliseks üliõpilaste õppimine ja selle toetamine. Sarnane areng õpetamispraktikas peegeldus ka mitmetest selle uurimuse intervjuudest.

Ma nagu tudengite heaks, et ma ei pane ainult sisu, vaid vorm on muutunud hästi oluliseks võrreldes varasemaga. Enne oli sisu oluline ja ma vormile üldse ei mõelnud, aga praegu need käärid ilmselt tähistavad seda, mismoodi ma selle asja nendeni viin või mismoodi see nendeni jõuab. (Socialia, 41A) 
Õppejõu rolli õppeprotsessis nähti seotuna õppeprotsessi korraldamisega („annan lugeda, rühmitan, liigun üliõpilaste vahel ja nemad töötavad”). Olulisena toodi esile õppejõu oskust kõrvale tõmbuda, kui on näha, et üliõpilane saab ise hakkama - sel viisil toetatakse üliõpilase kui ennast juhtiva õppija kujunemist. Valitud fotode kaudu kirjeldati õppejõudu kui suunajat, toetajat või innustajat ning samas väljendati veendumust, et õppima peab ikkagi üliõpilane ise (vt foto 1).

Õppejõud ongi just see tugi seal väikese puu ümber, aga see puu ikkagi põhimõtteliselt peaks ise kasvama. See õpetamisprotsess on pigem selline, et õppejõud küll aitab ja teeb, aga mida me üliõpilases hindame, on ikkagi see iseseisvus. (Humaniora, 16A)

Mitmes intervjuus kirjeldati õpetamist kui suunamist, suuna näitamist ning õppejõudu kui suunajat (suunaviita). Samuti toodi välja, et üliõpilasel peab olema võimalus ise valikuid teha (vt foto 2 ).

Õpetamine on kui suuna näitamine, info edastamine. Õppejõud on nagu see suunaviit (...), mis suunab inimest, jagab infot. Siis inimene ise otsustab seal teel olles, kuidas ta seda infot kasutab või kuhu suunas ta liigub, lähtuvalt sellest, millist informatsiooni talle on jagatud. Õppejõud ei ole see, kes sunnib, et mine nüüd sinna, vaid ta annab valikuvõimalusi ja infot, mille põhjal inimene saab otsustada. (Socialia, $32 \mathrm{~A})$

Mitmete metafooride ja muude kujundite kaudu rõhutati intervjuudes mõlema, nii üliõpilase kui ka õppejõu vastutust ja pühendumist õppimis- ja õpetamisprotsessis: „Õpetamine on puhas, lihtne, elegantne ja tasakaalustatud tegevus, kus on vajalik nii õpetaja kui õppija hing" (realia et naturalia, 8A). Arutluse ajendiks oli näiteks veepiisk kui selgust ja puhtust peegeldav kujund (vt foto 3).

Oma tõekspidamisi kirjeldades rõhutasid mitmed intervjueeritud õppejõud, et nende jaoks on õpetamine ja õppimine üks protsess, mida ei ole mõtet lahutada, ning nad selgitasid õpetamist ja õppimist ühe ja sama pildi kaudu. Õpetamist ja õppimist tõlgendati kui ühist ehitamist. Õpetamise eesmärk on saada üliõpilased õppima. Samuti rõhutati, et õpetamise käigus õpib ka õppejõud ise.

Nii nagu Postareffi ja Lindblom-Ylänne (2008) ning Sadleri (2012) uurimuses, tõid ka käesolevas uurimuses osalenud õppimiskeskse õpetamisarusaamaga algajad õppejõud välja, et õpetamine on koostöö, õppejõu ja üliõpilase ühine tegevus püstitatud eesmärgi nimel. Koostöö seostus nende õppejõudude jaoks ka kahepoolse suhtlemisega ning tagasiside olulisusega, 


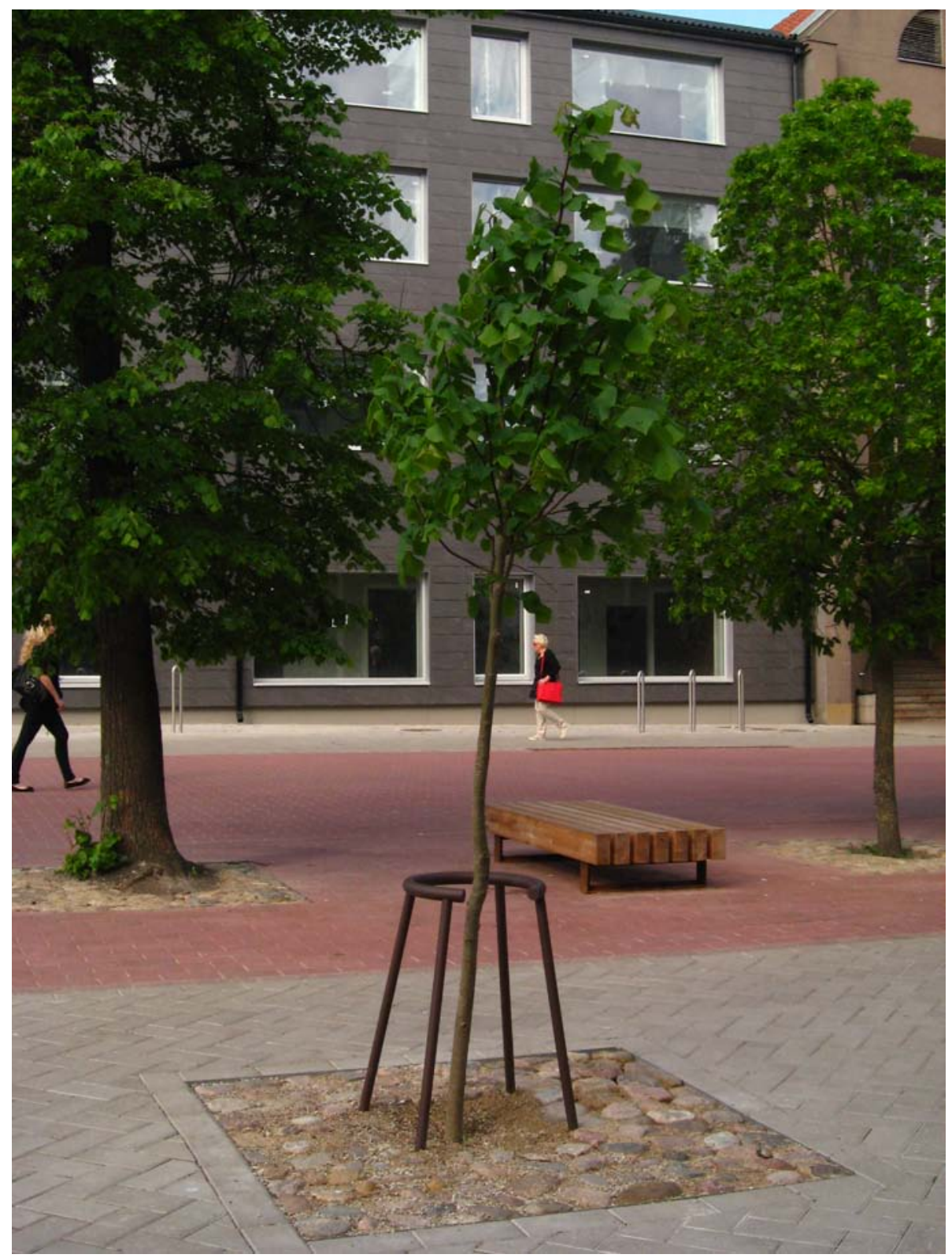

Foto 1. Arusaam õppejõu rollist

mis tähendab, et nad on hakanud loengutes ja seminarides andma üliõpilastele ülesandeid, mille põhjal nad saavad juba loengukursuse käigus aru, kas ja kuidas üliõpilased on õpitavat materjali mõistnud. 


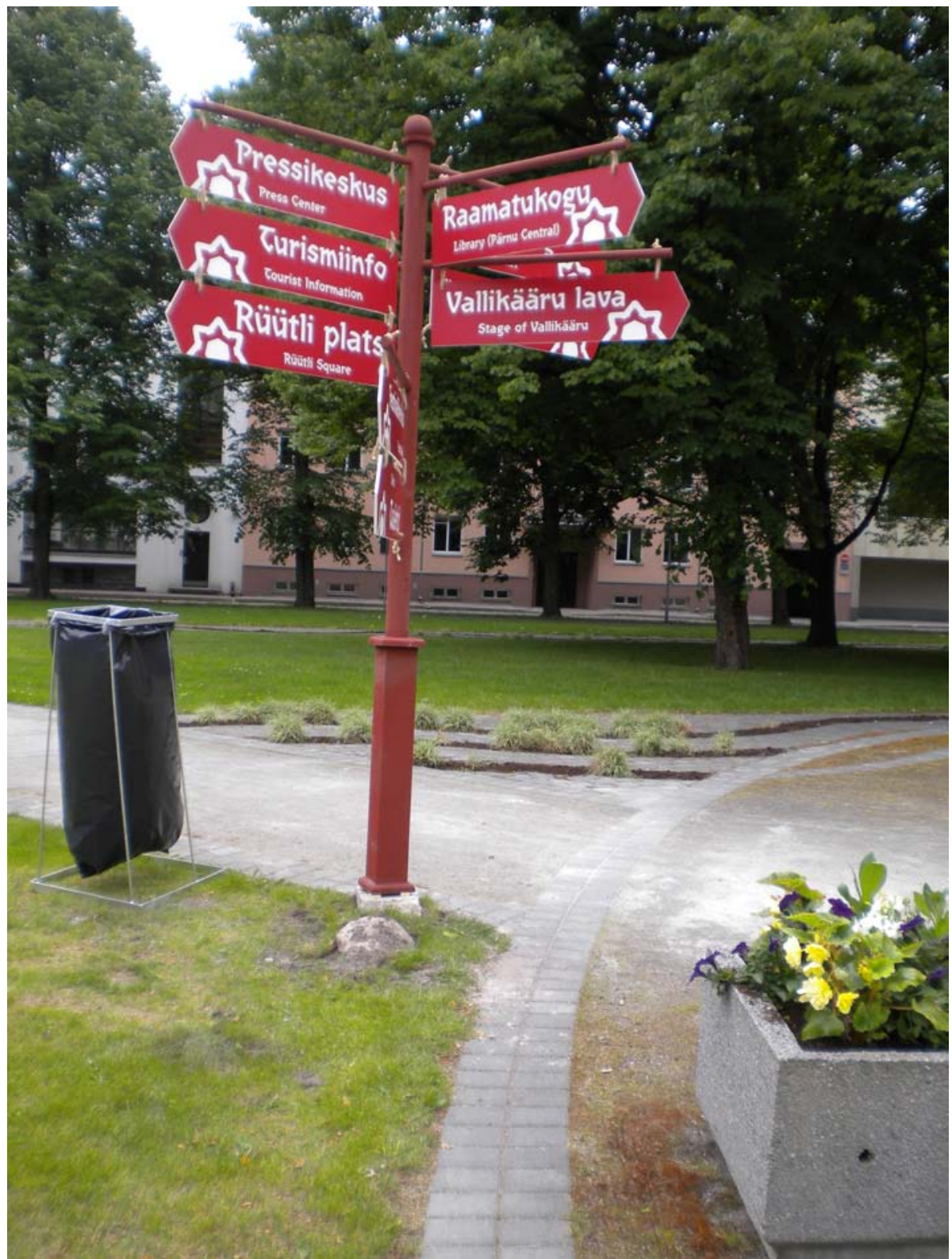

Foto 2. Arusaam õpetamisest 


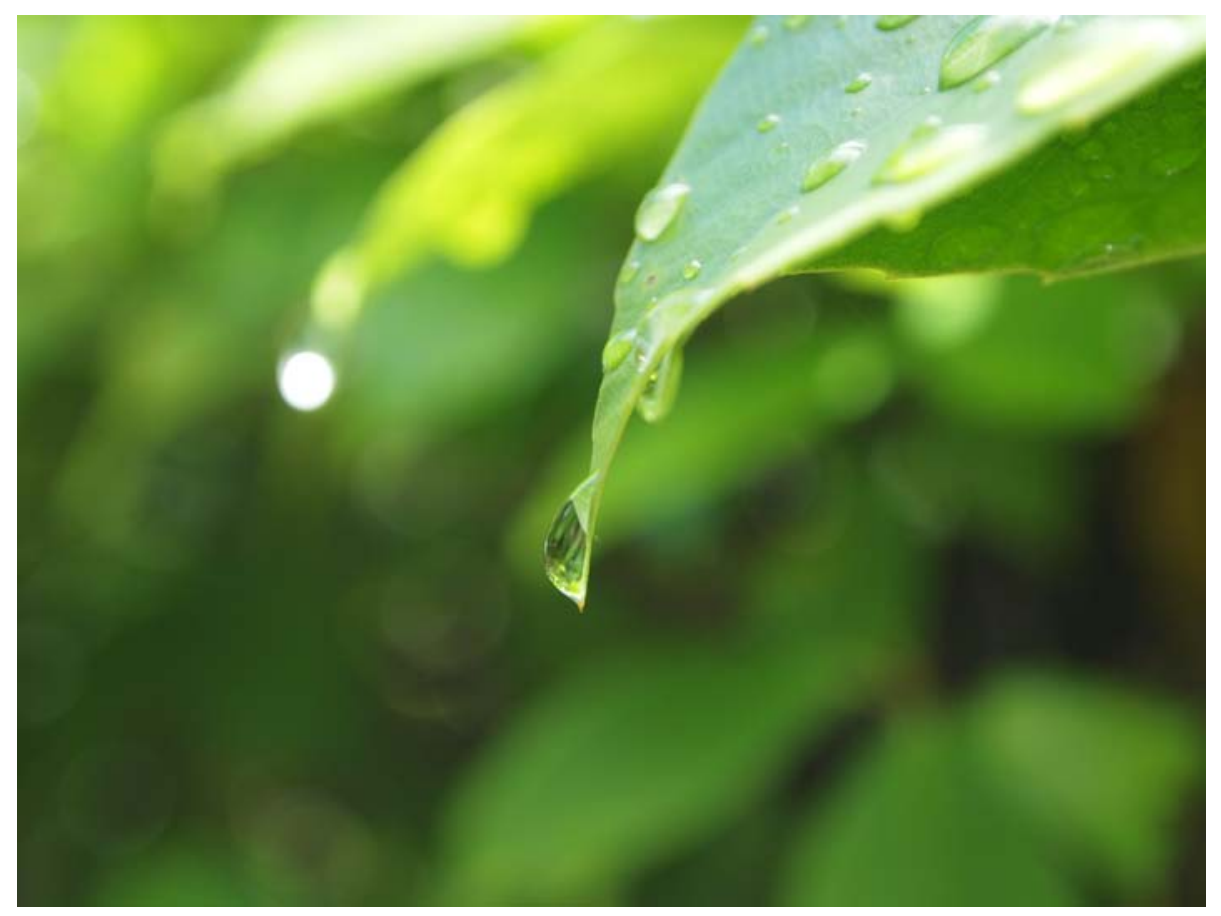

Foto 3. Arusaam õpetamisest

No ma arvan, et üks vahe on juba selles, et ma enne üldse ei teadnud, mida nad õpivad, ma sain ju ainult lõpu tagasisidest teada, sest vahepeal ei küsinud, ei teinud refleksioone, ei lasknud nagu peegeldada seda kõike. (...) Et mis neile kohale jõuab või mitte, et kas nad õpivad või mitte, ma ei teadnud seda. Nüüd kui ma tagasisidet sellises vabamas vormis küsin, siis ma saan sisust paremini teada. (Socialia, 41A)

N. Entwistle, Skinner, D. Entwistle ja Orr (2000) toovad välja, et head õpetamist võib määratleda kui avaramat teadlikkust õppimise ja õpetamise seostest. Nicholls (2005) järeldab oma uurimuse põhjal, et vaid üksikud algajad õppejõud märkavad seost õpetamise ja õppimise vahel. Need õppejõud näevad üliõpilases õppijat, mitte pelgalt teadmiste ja info vastuvõtjat. Fotointervjuude põhjal võib väita, et mitmed algajad õppejõud teadvustasid üsna selgesti, et õpetamine ja õppimine on omavahel seotud tegevused, ning nad suhtusid üliõpilastesse kui iseseisvatesse õppijatesse.

Üks teemadest, mille üle õppimiskeskse õpetamisarusaamaga õppejõud intervjuudes arutlesid, on suhted üliõpilastega. Sama moodi nagu Åkerlindi (2004) ja van Drieli jt (1997) uurimustes, osutati ka siin, et suhtlus võiks toimuda võrdne võrdsega põhimõttel ning mõlemal poolel võiksid olla oma 
kohustused ja vastutusalad. Õppejõud on märganud, et õppejõu suhtlemise laad võib mõjutada üliõpilaste õppimist. Samas nenditi, et keeruline on leida sobivat suhtlemisstiili. Ühelt poolt tahaksid nad üliõpilasi toetada, sest on näha, et üliõpilased vajavad suunamist, samas ei soovita olla ka ülearu hoolitsev. Sobiva suhtlemisstiili leidmise võib teha keeruliseks ka see, et noortel õppejõududel ei ole head eeskuju või mudelit, mille järgi toimida. Meenutades ennast üliõpilasena, tuli neile enamasti meelde suur vanusevahe ja distants oma õppejõududega. Praegu tekitas neil noorte õppejõududena raskusi nii sobiva suhtlemisviisi leidmine kui ka üliõpilastega piiride seadmine.

Ennem ma arvasin, et see tudengi ja õppejõu distants peab olema nagu suurem. Mul on olnud nagu tohutu respekt oma õppejõudude suhtes. Hästi raske on nagu saavutada seda, et noh tudengid, kuidas ma suhtlen niimoodi nagu normaalne inimene. (Realia et naturalia, 8A)

Õppimiskeskse õpetamisarusaamaga õppejõududest eristusid need intervjueeritud õppejõud, kes väljendasid väga selgeid ja traditsioonilisi ettekujutusi õpetamisest: ülikool peab andma akadeemilist haridust ning sellega seostub ka akadeemiline loenguline õpetamisviis (sisukeskne õpetamisarusaam).

Mõned traditsioonilised asjad nagu loengu pidamine ja tahvli peale kriidiga kirjutamine on see parem ja eeldatav õpetamisviis ikkagi, et seda akadeemilist haridust anda. (Realia et naturalia, 14A)

\section{Õppejõudude arusaam õppimisest}

Postareffi ja Lindblom-Ylänne (2008) uurimusest selgus, et õppimis- ja sisukeskse õpetamisarusaamaga õppejõud tajuvad ja kirjeldavad õppimist erinevalt. Nii näevad õppimiskeskse õpetamisarusaamaga õppejõud õppimisena eeskätt kriitilise mõtlemise arendamist ja oma arusaamade konstrueerimist. Sisukeskse õpetamisarusaamaga õppejõud peavad õppimiseks õigete vastuste andmist, meeldejätmist, olulise äraõppimist.

Käesoleva uurimuse raames intervjueeritud algajad õppejõud käsitasid õppimist samuti viisil, mis peegeldab erinevaid arusaamu. Ôppimist kirjeldati kui õppejõu pakutud teadmiste omandamist, kuulamist ja meeldejätmist, ent samuti kui oma arusaamade konstrueerimist, ühist óppimist ja koostööd. Õppimise puhul toodi esile, et sel on alati eesmärk, samas leiti, et eesmärgini võib jõuda erineval moel. Õppimist seostati ka kogemuste järkjärgulise omandamisega, mis igal järgmisel korral viib parema tulemuseni, nt õppimise metafoor intervjuust „tegin kooki ja iga kord kui teen, tuleb paremini välja" (socialia, 40A). 
Arutlustes õppimise üle toodi algajate õppejõudude intervjuudes välja ka elukestva õppimise idee, nt Sagrada Família foto, mis loob ettekujutuse selle ehitamisest „kui üle mitme elu kestvast protsessist” (socialia, 10A), peegeldades õppimise järjepidevust.

Samuti seostusid õppimisega erinevad tunded - mõnu, ilu, kord, uudishimu -, samas võib õppimine olla ka eksitav, keeruline, raske, hägune. Mitmes intervjuus valiti just õppimist kirjeldades üliõpilase vaatenurk ning meenutati enda õppimist üliõpilasena. Oma õppimiskogemusi käsitati pigem individuaalse tegevusena, mis seisnes uue info tuupimises. Samas see individuaalne tuupimine seostuski õppejõudude ettekujutustes traditsioonilise ülikoolis õppimisega.

Mõtlesin kogu aeg, et vot ülikooli lähen, siis istun keset voodit, palju pabereid on ümberringi, ja raamatuid, ja nii see õppimine käibki. Ja siis kui mõnikord endal juhe koos oli, istusin kodus paberite keskel ülikooli ajal (...), et issand jumal küll, kui raske. (Socialia, 41A)

Kui algajate õppejõudude enda õppimiskogemused peegeldavad pigem individuaalset info omandamist, siis tekib küsimus, kuivõrd nad eeldavad sama või teistsugust õppimisviisi oma üliõpilastelt. Enda õppimiskogemus või sellega rahulolematus võib olla ka ajend püüelda õppimiskeskse õpetamise poole.

Ma olen natuke pahane enda hariduse peale, seda oleks saanud paremini anda. (....) Ja ma tahaksin, et mina oleksin natuke teistsugune. Et päike ei ole mitte kõrgel ja ei vaata imestunult alla, vaid on siin tudengite seas. (Realia et naturalia, 31A)

Samas on arusaam õppimisest kui individuaalsest tegevusest kooskõlas Eleni jt (2007) uurimusega, milles osutatakse samuti, et õppejõud kalduvad õpetamiskontekstis tõlgendama õppimist eeskätt individuaalse tegevusena.

\section{Algaja õppejõu areng õppejõuna}

Õppejõuna professionaalselt tegutsemiseks on oluline valmisolek arendada ennast nii õpetaja kui ka teadlasena. Algajad õppejõud kirjeldasid ennast ja oma tegevust õppejõuna viisil, mis väljendab ühtaegu teadmatust (puudub selge ettekujutus endast kui õppejõust) ja ebakindlust: „Ma tahtsin otsida udu pilti. Ma tõepoolest ei tea, milline ma olen õppejõuna" (realia et naturalia, 32A). Intervjuudes toodi esile oskuste ja kogemuste vähesus ning sellega seonduvad probleemid. 
Intervjueeritavad osutasid, et esialgu on põhiline n-ö rajale jääda (hakkama saada) ja situatsiooniga toime tulla. Sarnased kahtlused toovad oma uurimistulemuste põhjal välja ka McAlpine jt (2009), kes väidavad samuti, et esialgu püüab algaja õppejõud ellu jääda, alles seejärel mõtleb ta sobivatele õpetamisstrateegiatele ja sellele, millised tegevused tegelikult üliõpilaste õppimist toetavad.

Seda algaja ellujäämismeeleolu kirjeldati õppejõu kui rallisõitja kujundi kaudu (vt foto 4): õpetamine on pidev enese proovilepanek ning õppejõus peab olema valmidust kiiresti reageerida.

Täpselt nii ma olen ennast tundnud väga paljudes olukordades: et jalad maast lahti. Et ma paremat pilti ei leidnud ja ma mõtlesin, et see oli ainukene, kus oli auto ja neli ratast õhus. Ma usun, et mitte ainult algajad õppejõud, vaid ka vanad õppejõud uutes situatsioonides võivad tunda ennast sarnaselt. Või grupid on erinevad, et iga kord, kui sa alustad mingit ringi, siis sa tegelikult ju kompad ja oledki nagu jäärajal, et kas nüüd lähen välja või jään rajale. (Socialia, 10A)

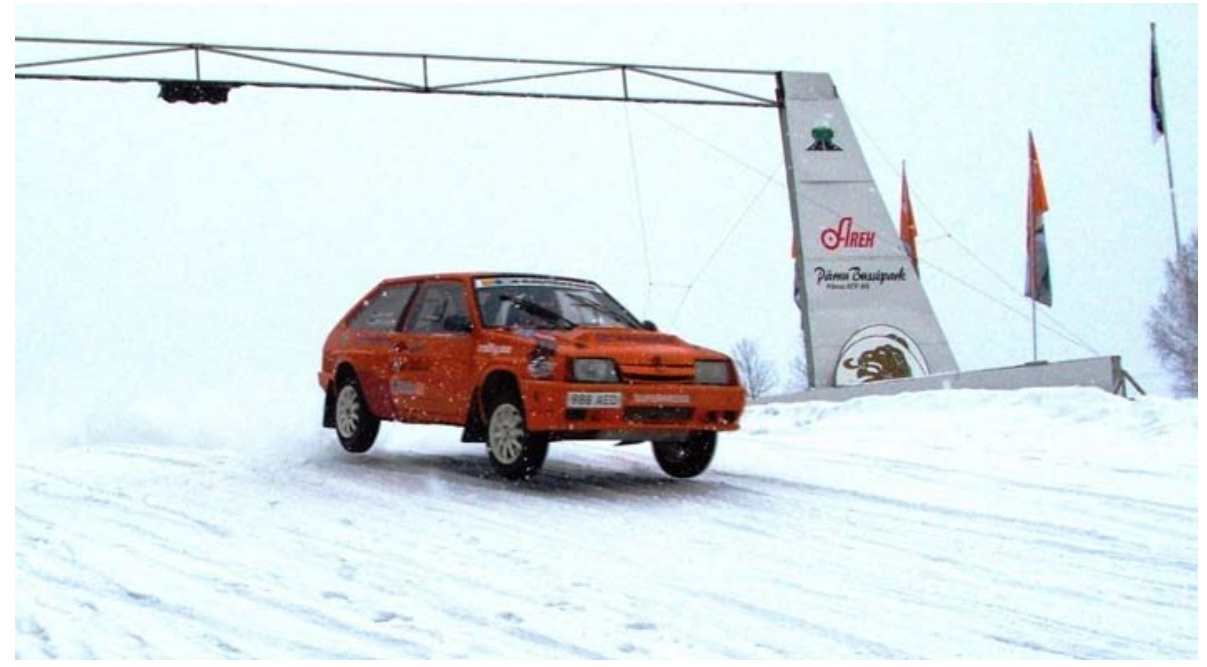

Foto 4. Algaja õppejõud

Teisalt märkasid intervjueeritavad enda muutumist ka selle lühikese aja jooksul, mil nad on õppejõuna töötanud. Nad tõid välja, et nad pole enam sellised õppejõud, kes alguses. Mõni intervjueeritav väljendas otse, et „loengupidamise perioodist olen läbi tulnud” (socialia, 41A). Intervjuus loetleti, milliseid oskusi ollakse enda hinnangul omandanud, nimetati näiteks 
planeerimisoskust, õppetöö korraldamise oskusi, suuremat mitmekesisust õppemeetodite kasutamisel, tagasiside andmise oskust ning ladusamat suhtlemist üliõpilastega.

Intervjueeritud algajad õppejõud pidasid jätkuvat arenemist oluliseks. Kui kujundlikult kirjeldati õppejõudu kui tuge, mis toetab üliõpilase kasvamist, siis rõhutati ka seda, et see „tugi peaks ise ka kasvama” (humaniora, 16A) (vt foto 1). Arenemist väärtustades muretseti samas võimaliku stagneerumise ja kivinemise pärast. Algajate õppejõudude muretsemise tausta moodustab isiklik kogemus enda üliõpilasajast, kui on tulnud óppida sära kaotanud ja rutiini sattunud õppejõudude juhendamisel.

Postareffi ja Lindblom-Ylänne (2008) uurimus näitab, et õppejõu arusaamad enda arenguvajadustest on seotud óppejõu pedagoogilise teadlikkusega, st sellega, kui palju õppejõud reflekteerivad oma õpetamist ning räägivad sellest analüütiliselt. Åkerlind (2003) leiab, et mida professionaalsem on õppejõud, seda enam ta analüüsib oma praktikat, et mõista, millised õpetamisstrateegiad toetavad üliõpilaste õppimist ja millised mitte. Mitmete õppejõudude intervjuudest selgus, et nad analüüsivad pidevalt oma praktikat ning püüavad leida keerulistele olukordadele lahendusi.

Kui sa hiljem neid eksamitulemusi näed, siis sa näed ka, et ühes valdkonnas antakse kogu aeg valesid vastuseid. See tähendab seda, et see ei ole mitte tudengite viga, vaid ikkagi mina ise olen teinud midagi, mis on pannud nad valesti aru saama ... Ei saa olla nii, et mitte keegi ei valda seda või ei õppinud ära. (Realia et naturalia, 29A)

Nicholls (2005) toob oma uurimuse põhjal välja, et algajad õppejõud nägid enda arendamise vajadusi just seotuna uurimistööga ja selle tulemuste avaldamisega ning väga vähesed tundsid vajadust arendada õpetamisoskust või pühenduda õpetamisele. Fotointervjuudes osalenud õppejõud väärtustasid ka õpetamisoskuste arendamist: „Praegu ma tunnen, et mul on ikkagi vaja esiteks seda kogemust ja just seda metoodilist poolt. (...) Et rohkem nagu katsetada julgemalt" (socialia, 10A).

Õpetamisarusaamade muutumine. Õpetamist puudutavates aruteludes tuleviku üle tuli ilmsiks tasakaalu otsimine õppimis- ja õpetamiskeskse käsitlusviisi vahel. Ühelt poolt sooviti olla autoriteet, tohutute teadmistega ekspert, samas oli olemas selge arusaam, et ainult eksperdiks olemisest üliõpilaste õppimise toetamisel ei piisa. Intervjuu käigus märkas nii mõnigi intervjueeritav väikese üllatusega, kuidas valitud foto põhjal ilmnes, et tema arusaamades põimuvad ülikoolis levinud traditsioonilised arusaamad ja õppimiskesksed ideaalid. 
Ma usun, et ka minu peas on kuskil alateadvuses see mõte, et üks hetk seisan nagu prohvet seal nende tudengite ees ja kõik on tulnud mind kuulama ja minu sõna ongi tõde. (...) Võib-olla just sellepärast selle pildi valisin, et see on ülikoolis selline teatud mõttemall. (Realia et naturalia, 31A)

Fotointervjuude käigus toodi välja sobiva õpetamisviisi leidmisega seotud kõhklused ja otsingud. Üks intervjueeritavatest arutles, et ta on seni väärtustanud õppimiskeskset arusaama ja arendanud ennast üliópilasi kaasavate õppemeetodite kasutajana. Samas on ta jõudnud pöördepunkti: tal on tunne, et aktiivsed meetodid väsitavad teda ennast ja üliõpilasi ning võib-olla pole need küllalt sisukad. Ta väljendas ka oma kahtlusi, et aktiivsete õppemeetodite kasutamine võib teda tulevikus mitte päris tõsiseltvõetavaks muuta, mistõttu on tekkinud tunne, et tuleks rohkem loenguid pidada, aga päris loengukeskseks ei tahaks ta ka muutuda.

Fotointervjuudes väljendatud vaated annavad kinnitust narratiivintervjuudest ilmnenud tulemustele (Remmik \& Karm, 2013), et algajate óppejõudude arusaamad võivad olenevalt tingimustest muutuda nii õppimis- kui ka õpetamiskesksema suunas.

Intervjuudest ilmnes, et osa õppejõude on oma põhilise õpetamisviisi leidnud ning see võib olla kas rohkem õpetamis- või pigem õppimiskeskne. Ühelt poolt loodeti, et tulevikus läheb lihtsamaks: põhitelg saab paika ning tulevikus on seda võimalik edasi arendada ja täiendada nii materjalide kui ka töövõtetega. Loodeti enda tegevustes saavutada suuremat korrastatust ja süsteemsust.

Ma tahaks sisulises mõttes saavutada, et mul on mingisugune selgroog või skelett paigas, ja siis vastavalt, kui ma midagi juurde loen, siis ma saan materjali juurde tuua või vahetada mõne artikli värskema vastu või midagi nii. (...) Ma tean, millest ma räägin, ja siis ma panen lihtsalt sinna juurde need mängud või arutelud või mingid praktilised näited. (Socialia, 41A)

Osa intervjueeritute jaoks oli ka tulevikuplaanis õppejõuna endiselt oluline akadeemilisus, mille kujundiks on kriidiga tahvlile kirjutamine: „tahvlile tuleb kirjutada oluline, üliõpilane vaatab seda, kirjutab endale ümber ja see jääb talle meelde" (realia et naturalia, 14A).

Algaja õppejõu tulevikuvaade õppejõuks olemisele. See, millise õppejõuna ennast tulevikus nähakse, lähtub sellest, kuidas õppejõuks olemist olevikus tajutakse, ning oma tegevusest ja arusaamadest. Teisalt on ettekujutust õppejõutööst mõjutamas ka ülikoolis valitsevad normid ja ideaalid. Mõnes 
intervjuus väljendati kõhklusi, kas üldse jääda ülikooli - see puudutab eriti neid õppejõude, kes töötavad väljaspool ülikooli ka praktikuna. Teisalt rõhutati mitmes intervjuus suuremat kindlustunnet, mida loodetakse tulevikus õppejõuna tunda.

Mitmete intervjueeritavate puhul tuli teemaks vanus: kujutleti end märgatavalt vanemana ning tekkis küsimus, kuidas ühendada praegune nooruslik mina ja tuleviku vanem mina. Kasvav vanus tõi intervjueeritavate arutlustes esile toredaid külgi („kõrges vanuses tahaks olla elav ja hea esineja” (realia et naturalia, 6A)), kuid tekitas ka hirme võimaliku rutiini ja tüdimuse ees. Ühelt poolt kujutleti, et tulevikus ollakse kujunenud oma ala asjatundjaks, teadmiste ja kogemuste hulk on kasvanud ning see annab suurema mõjukuse, sisemise rahu ja vabadustunde. Samuti rõhutasid mitmed intervjueeritud elutarkuse tähtsust.

Kummuti kujundi kaudu tõi üks intervjueeritav välja laialdaste erialateadmiste, üldise silmaringi ja elukogemuse seosed ning tähtsuse. Samuti leidis intervjueeritav kummuti kujundit tõlgendades, et õpetamisel on oluline arvestada üliõpilastega ja nende õppimist toetada (vt foto 5).

See on üks selline kappkummut, ma mõtlesin, et see võiks välja näha väga selline lugupeetav kapp. Nii ja siis kindlasti selline suur, hästi palju mahutav kapp. Ja siis ma mõtlesin, et sellel kapil või kummutil peaks olema selliseid suuremaid sahtleid ja väiksemaid sahtleid (....) Suuremad sahtlid võiksid siis olla sellised, mis on nagu selle õppejõu enda teadustöö või erialaga seotud. Aga samas nagu sellest ühest erialast ei ole nagu nii palju kasu, sul peab olema ka väga palju muudest valdkondadest teadmisi. Ja siis ma mõtlesin, et kui nagu sa seda kapi sisu hakkad kasutama, et siis tegelikult on niimoodi, et iga üliõpilane, kellega sa kokku puutud, on erinev, ja et siis sa pead neid erinevaid sahtleid avama nende jaoks. (Socialia, 40A)

Tulevikuga seotud arutlustes ja kujundites kerkis esile ülikooli traditsioonist lähtuv tõekspidamine, et ülikoolis tuleb olla oma valdkonna ekspert, kes jagab kogutud tarkust üliõpilastele. Selline arusaam on iseloomulik õpetamiskesksele käsitlusviisile. Huvitava vastuoluna iseloomustas traditsiooniline eksperdi ettekujutus ka nende algajate õppejõudude tulevikupilte, kes oma olevikutegevustes on selgelt õppimiskesksed.

Kirjeldades enda tulevikku õppejõuna, toodi olulisena välja tahe säilitada elavus, entusiastlikkus ja rõõmsameelsus. Tunnetati, et noore õppejõuna ollakse entusiastlik, ent samas tunti muret, kas seda entusiastlikkust suudetakse hoida või kas sellest piisab. Enda oleviku- ja tulevikutegevuse seostamisel tekkisid ka küsimused, kas noore õppejõu tugevused osutuvad vanema 


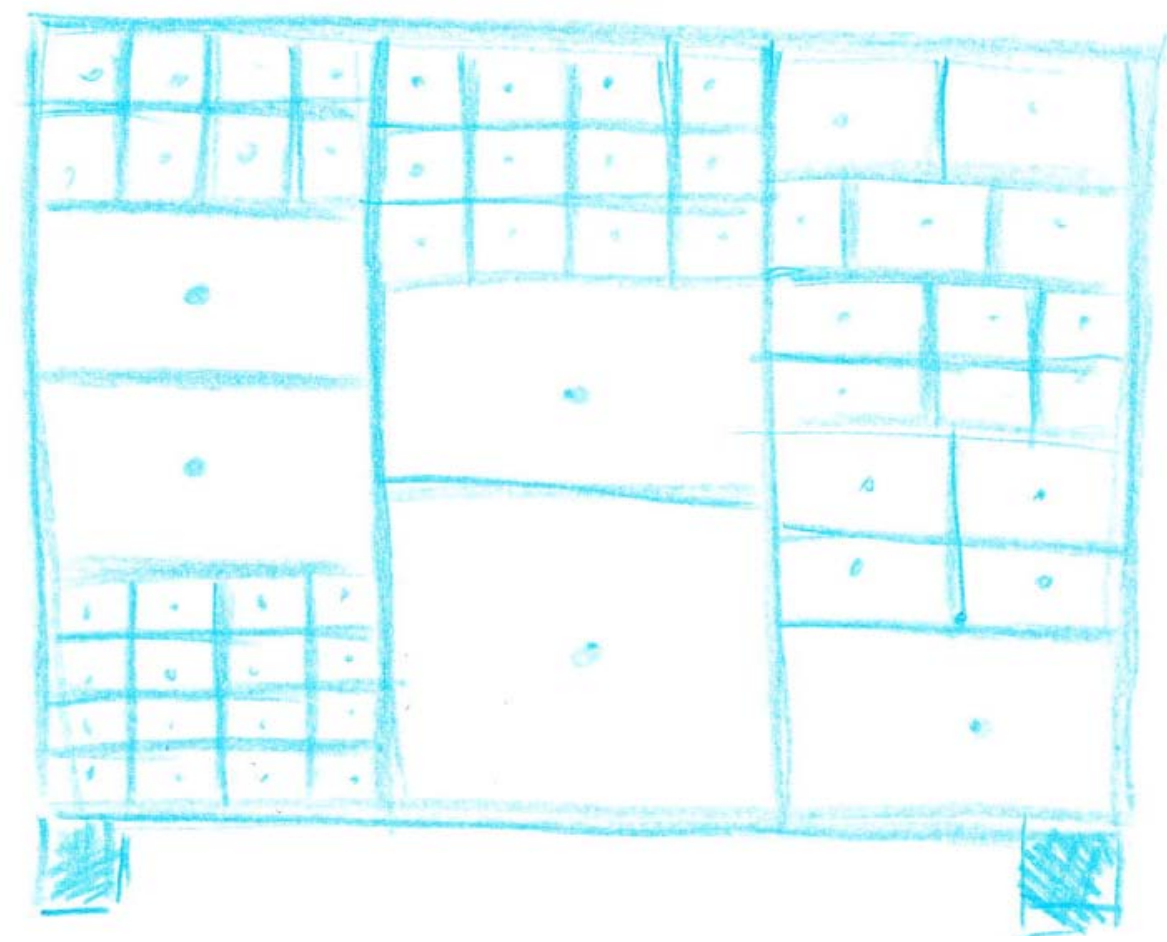

Foto 5. Õppejõu teadmised ja oskused

õppejõu puhul piisavaks või kas nad üldse on siis kohased („kas seda, mis ma praegu õppejõuna teen, sobib teha kogenud professorina?"). Nooruslikku hoogu ja sära väljendati kiikumise kujundi kaudu (vt foto 6).

Ja siis ma mõtlesin, et kõige olulisem ja mida mulle tegelikult tagasisides on öeldud, seal ÕISis, et ma olen entusiastlik ja nagu rõõmsameelne, selline avatud, ja tihti see vanusega kaob nagu ära. Mida kauem sa oled mingit ainet õpetanud, see kaob nagu ära. Ma ei kujutagi ette, kui ma sedasama ainet õpetan kümme aastat, et mis siis saab. (Realia et naturalia, 8A)

Tulevikupiltide kommentaarides olid olulisel kohal õppejõu inimlikud omadused: abivalmidus, vastutulelikkus, sõbralikkus („,̈̈liõpilane peab julgema küsida" (realia et naturalia, 8A)), inimlik suhtumine, otsekohesus ja empaatilisus. Õppejõu puhul tõsteti esile üldist inimlikku poolt, seda, kuidas ta oma tööd korraldab ja inimestega suhtleb ning mille kaudu ta annab edasi ,oskust elus hakkama saada" (realia et naturalia, 8A).

Algaja õppejõu tulevikuvaadet mõjutasid nii isiklik huvi ja motivatsioon töötada õppejõuna ülikoolis kui ka toetava kogukonna olemasolu ja suhted 


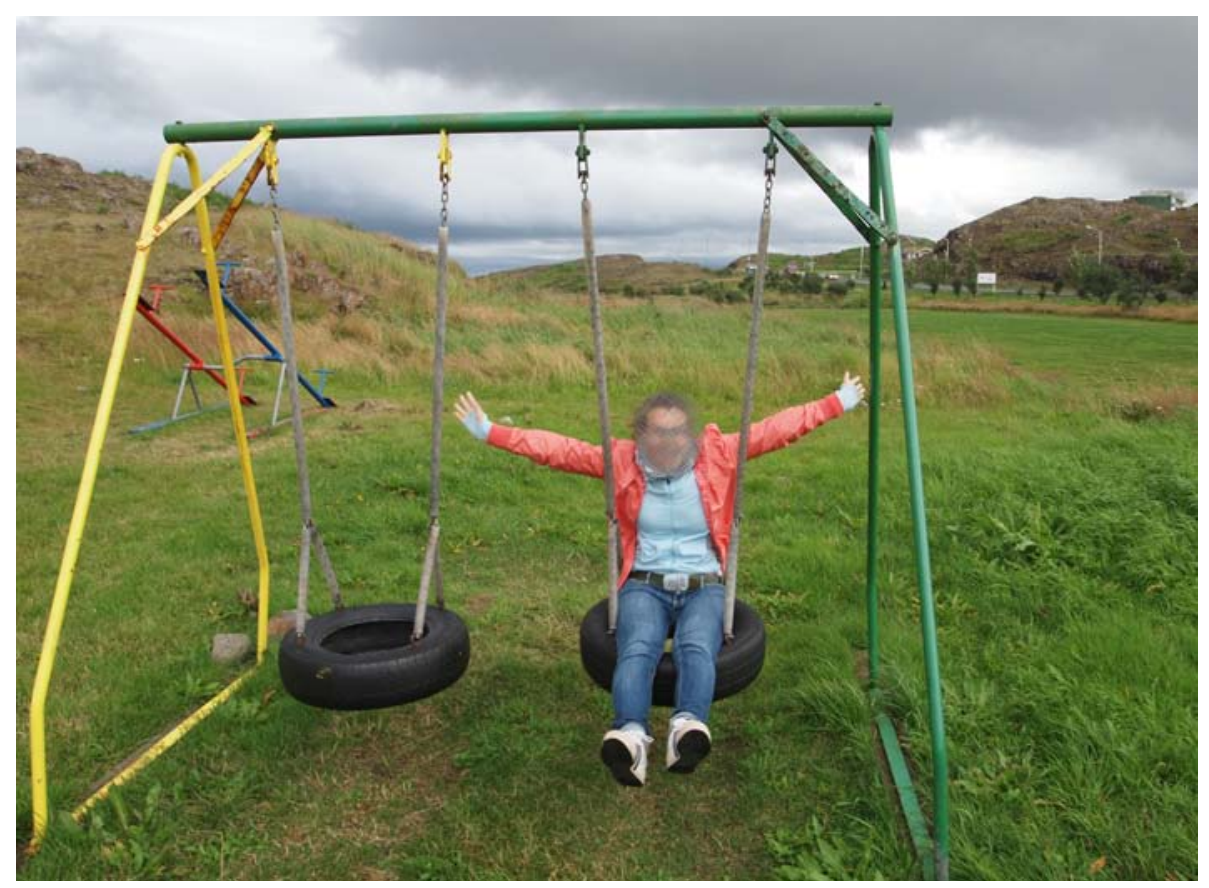

Foto 6. Kujutlus enda kui õppejõu tulevikust

algaja õppejõuga. Õpetamisarusaamade kujunemisel on tähtis, et akadeemilistes struktuuriüksustes arutletaks õpetamisega seotud teemasid ning oldaks valmis oma õpetamispraktikat reflekteerima ja olemasolevaid õpetamisarusaamu jagama.

\section{Järeldused}

Fotode kasutamine uurimuses andis koostöise uurimistöö kogemuse, sest osalevatel õppejõududel oli võimalus tunda end aktiivse uurimuses osalejana. Fotointervjuud võimaldasid intervjueeritavaga korduvalt kohtuda ning selle tulemusena tekkis lähedasem kontakt, mis lõi eelduse avatud aruteludeks. Fotode tegemine või otsimine kaasas intervjueeritavaid uurimusse ning juhtis neid sügavamalt reflekteerima enda arusaamu: „[pilte otsides] sa hakkadki mõtlema nagu natukene sissepoole, sa hakkadki mõtlema, mis see siis on, see mis teeb õppejõust õppejõu ja õpilasest õpilase" (realia et naturalia, 8A).

Uurimusest ilmnes, et ehkki fotode kasutamine toetab arutelu käivitamist intervjuu algul ja võimaldab tõlgendada õppejõudude arusaamu õpetamisest, on fotointervjuul andmete kogumise vahendina oma piirangud. Näiteks loobusid mitmed algaja óppejõu uurimuses osalejad fotointervjuust, tuues 
välja, et fotodega tegelemine võtab liiga palju aega ja energiat, neile ei sobi pildistamine või neil puudub kujundlik mõtlemine. Seetõttu võib valim olla kallutatud: uurimuses osalesid need algajad õppejõud, kelle jaoks fotointervjuu uurimismeetodina tundus huvitav ja sobiv.

Uurimus näitas, et algajat õppejõudu kui rühma ei või käsitleda lihtsustatult, sest algajad õppejõud ei ole ühesugused. Nad võivad erineda nii teadustöösse ja õpetamisse suhtumise kui ka õpetamisarusaamade poolest, samuti võib nende valmisolek muutuda, ennast arendada ja õppida olla inimesiti erinev. Intervjuudes väljendati oma kõhklusi ja otsinguid. Osutati, et ülikoolitöö võib olla ühele või teisele poole kaldu. Väljendati soovi leida sobiv tasakaal erinevate tegevuste, nt õpetamise, teadustöö ja praktilise tegevuse vahel või õppimis- ja õpetamiskeskse käsitlusviisi vahel, ning üliõpilastega suhtlemise stiil. Mõned intervjueeritud tõid selgesti esile, et nende jaoks on peamine õpetamine. Osa intervjueeritud õppejõududest rõhutas, et just teadusega tegelemine pakub ülikoolis töötamisel huvi, ning nad on veendunud, et teadustöö loob aluse õppejõu professionaalsusele ning aitab ka õpetamist huvitavamaks teha.

Fotointervjuude analüüsi põhjal saab välja tuua järgmised võimalikud suundumused.

1. Traditsioonilised õppejõud. Selle rühma esindajad ei mõtle eriti õpetamise üle, nad õpetavad kõhklusteta traditsioonilisel viisil ning ei too välja enda edaspidise professionaalse arendamise vajadusi ega kavatsusi.

2. Kahtlevad ja otsivad óppejõud. Selle rühma esindajad arutlevad õpetamise üle, kuid ei ole oma õpetamisviisis kindlad. Nad võivad küll olla õppimiskesksed, kuid samas kahelda, kas see on kõige sobivam viis ülikoolis õpetamiseks.

3. Oma tee leidnud õppejõud. Selle rühma esindajad mõtlevad õpetamise üle, nad on läbi teinud muutusi ning neile tundub, et nad on leidnud ülikoolis töötamise ja õpetamise viisi, mida kavatsevad jätkata ja edasi arendada.

Algajate õppejõudude erinevuste mõistmine võimaldab ülikoolides algajaid õppejõude nende õpetamisoskuste arendamisel sihipäraselt toetada, kuna erinevad õppejõud vajavad erinevat laadi toetust.

Algajate õppejõudude arusaam õpetamisest võib olla nii õpetamis- kui ka õppimiskeskne. Uurimus kinnitas varasemate uurimuste tulemusi, et algajatel õppejõududel võib olla õppimiskeskne arusaam, aga neil võib olla raskusi seda praktikas realiseerida (Mälkki \& Lindblom-Ylänne, 2012), sest neil puuduvad vajalikud oskused, töövõtted, õppemeetodid või sobiv keskkond (kolleegide toetus).

Õppejõu tulevikukujutlused lähtuvad ühelt poolt tema enda olevikutegevusest ja arusaamadest, teisalt mõjutavad neid kujutlusi ka ülikoolis 
valitsevad normid ja traditsioonid. Kujutletakse, et tulevikus ollakse kujunenud oma ala asjatundjaks, teadmiste ja kogemuste hulk on kasvanud ning see annab suurema mõjukuse. Arutlustes ja kujundites kerkib esile arusaam, et ülikoolis tuleb olla oma valdkonna mõjukas ja lugupeetud ekspert, kes jagab kogutud tarkust üliõpilastele (õpetamiskeskne arusaam). Traditsiooniline õpetamiskeskne ettekujutus avaldub ka nende algajate õppejõudude puhul, kes oma olevikutegevustes on õppimiskesksed.

Just fotode kaudu ilmnes ülikooli traditsioonide ja normide osa algajate õppejõudude arusaamades, mis oli üllatav ka intervjueeritavatele endile. Fotointervjuud tõid esile vastuolud intervjueeritud õppejõudude õpetamisarusaamades, nt sama õppejõud võis mõne teema puhul väljendada pigem õppimiskeskseid, kuid teise teema juures pigem õpetamiskeskseid seisukohti.

Algajate õppejõudude edasine areng võib kulgeda erinevas suunas. Algaja õppejõud võib muutuda õpetamiskesksemaks iseenda väsimise, üliõpilaste vastuseisu või ülikooli traditsioonide survel. Samas võib ta muutuda ka õppimiskesksemaks, kui tal õnnestub omandada vajalikud oskused, töövõtted ja õppemeetodid või leida toetav keskkond (kolleegide toetus). Samuti on õppejõudude arusaamade mõistmine abiks pedagoogiliste kursuste sisu kavandamisel ning rõhuasetuste seadmisel - kursustel tulekski pöörata tähelepanu sellele, et erinevates kontekstides mõistetakse õppimist erinevalt, kuid tähtsad on ka suhted üliõpilastega ning teadustöö ja õpetamise seostamine.

\section{Tänusõnad}

Uurimistööd on toetanud Euroopa Liit programmi Primus (projekti nr 30.34/826) rahalistest vahenditest.

\section{Kasutatud kirjandus}

Åkerlind, G. S. (2003). Growing and developing as a university teacher - Variation in meaning. Studies in Higher Education, 28(4), 375-390. http://dx.doi.org/10.1080/0307507032000122242

Åkerlind, G. S. (2004). A new dimension to understanding university teaching. Teaching in Higher Education, 9(3), 363-375. http://dx.doi.org/10.1080/1356251042000216679

Åkerlind, G. S. (2008). Growing and developing as a university researcher. Higher Education, 55(2), 241-254. http://dx.doi.org/10.1007/s10734-007-9052-x

Åkerlind, G. S., \& McAlpine, L. (2010). Rethinking preparation for academic careers. In L. McAlpine \& G. S. Åkerlind (Eds.), Becoming an academic: International perspectives (pp. 155-170). Hampshire, New York: Palgrave Macmillan. 
Billot, J. (2010). The imagined and the real: Identifying the tensions for academic identity. Higher Education Research and Development, 29(6), 709-721.

http://dx.doi.org/10.1080/07294360.2010.487201

Boyd, P., \& Harris, K. (2010). Becoming a university lecturer in teacher education: Expert school teachers reconstructing their pedagogy and identity. Professional Development in Education, 36(1-2), 9-24. http://dx.doi.org/10.1080/19415250903454767

Brew, A. (2010). Imperatives and challenges in integrating teaching and research. Higher Education Research and Development, 29(2), 139-150. http://dx.doi.org/10.1080/07294360903552451

Coate, K., Barnett, R., \& Williams, G. (2001). Relationships between teaching and research in higher education in England. Higher Education Quarterly, 55(2), 158-174. http://dx.doi.org/10.1111/1468-2273.00180

Cortazzi, M., \& Jin, L. (2006). Asking questions, sharing stories and identity construction: Sociocultural issues in narrative research. In S. Trahar (Ed.), Narrative research on learning: Comparative and international perspectives (pp. 27-47). Oxford: Symposium Books.

Debowski, S. (2012). The new academic: A strategic handbook. Maidenhead, Berkshire; New York: Open University Press.

Elen, J., Lindblom-Ylänne, S., \& Clement, M. (2007). Faculty development in researchintensive universities: The role of academics' conceptions on the relationship between research and teaching. International Journal for Academic Development, 12(2), 123-139. http://dx.doi.org/10.1080/13601440701604948

Eley, M. G. (2006). Teachers' conceptions of teaching, and the making of specific decisions in planning to teach. Higher Education, 51(2), 191-214. http://dx.doi.org/10.1007/s10734-004-6382-9

Entwistle, N., Skinner, D., Entwistle, D., \& Orr, S. (2000). Conceptions and beliefs about "good teaching": An integration of contrasting research areas. Higher Education Research and Development, 19(1), 5-26.

Erkkilä, R., \& Mäkelä, M. (2002). Face to face: Human dimensions in biographical interviews. In R. Huttunen, H. L. T. Heikkinen \& L. Syrjälä (Eds.), Narrative research: Voices of teachers and philosophers (pp. 45-55). Jyväskylä: SoPhi, Jyväskylän Yliopisto.

Fanghanel, J. (2012). Being an Academic. London, New York: Routledge.

Gonzáles, C. (2011). Extending research on „conceptions of teaching”: Commonalities and differences in recent investigation. Teaching in Higher Education, 16(1), 65-80. http://dx.doi.org/10.1080/13562517.2010.507302

Guzmán-Valenzuela, C. (2013). Challenging frameworks for understanding teaching practices in higher education: The end or the beginning? Qualitative Research in Education, 2(1), 65-91.

Harper, D. (2002). Talking about pictures: A case for photo elicitation. Visual Studies, 17(1), 13-26. http://dx.doi.org/10.1080/14725860220137345

Hurworth, R. (2003). Photo-interviewing for research. Social Research Update 40. http://sru.soc.surrey.ac.uk/SRU40.html.

Kember, D. (1997). A reconceptualization of the research into university academics' conceptions of teaching. Learning and Instruction, 7(3), 255-275. http://dx.doi.org/10.1016/S0959-4752(96)00028-X

Kugel, P. (1993). How professors develop as teachers. Studies in Higher Education, 18(3), 315-328. http://dx.doi.org/10.1080/03075079312331382241 
Kvale, S. (2006). Dominance through interviews and dialogues. Qualitative Inquiry, 12(3), 480-500. http://dx.doi.org/10.1177/1077800406286235

Lindblom-Ylänne, S., Trigwell, K., Nevgi, A., \& Ashwin, P. (2006). How approaches to teaching are affected by discipline and teaching context. Studies in Higher Education, 31(3), 285-298. http://dx.doi.org/10.1080/03075070600680539

Malcolm, J., \& Zukas, M. (2009). Making a mess of academic work: Experience, purpose and identity. Teaching in Higher Education, 14(5), 495-506. http://dx.doi.org/10.1080/13562510903186659

McAlpine, L., \& Amundsen, C. (2009). Identity and agency: Pleasures and collegiality among the challenges of the doctoral journey. Studies in Continuing Education, 31(2), 109-125. http://dx.doi.org/10.1080/01580370902927378

McAlpine, L., Amundsen, C., Clement, M., \& Light, G. (2009). Rethinking our underlying assumptions about what we do and why we do it: Academic development as a case. Studies in Continuing Education, 31(3), 261-280. http://dx.doi.org/10.1080/01580370903271461

McAlpine, L., \& Weston, C. (2000). Reflection: Issues related to improving professors' teaching and students' learning. Instructional Science, 28(5), 363-385. http://dx.doi.org/10.1023/A:1026583208230

Mälkki, K., \& Lindblom-Ylänne, S. (2012). From reflection to action? Barriers and bridges between higher education teachers' thoughts and actions. Studies in Higher Education, 37(1), 33-50. http://dx.doi.org/10.1080/03075079.2010.492500

Nevgi, A., \& Löfström, E. (2013). Visualisations as a means for exploring academics' teacher identities. International Journal of Academic Development. Published online 01.08.2013, http://dx.doi.org/10.1080/1360144X.2013.823545

Nicholls, G. (2005). New lecturers' constructions of learning, teaching and research in higher education. Studies in Higher Education, 30(5), 611-625. http://dx.doi.org/10.1080/03075070500249328

Norton, L., Aiyegbayo, O., Harrington, K., Elander, J., \& Reddy, P. (2010). New lecturers' beliefs about learning, teaching and assessment in higher education: The role of the PGCLTHE programme. Innovations in Education and Teaching International, 47(4), 345-356. http://dx.doi.org/10.1080/14703297.2010.518426

Norton, L., Richardson, J. T. E., Hartley, J., Newstead, S., \& Mayes, J. (2005). Teachers' beliefs and intentions concerning teaching in higher education. Higher Education, 50(4), 537-571. http://dx.doi.org/10.1007/s10734-004-6363-Z

Postareff, L., \& Lindblom-Ylänne, S. (2008). Variation in teachers' descriptions of teaching: Broadening the understanding of teaching in higher education. Learning and Instruction, 18(2), 109-120. http://dx.doi.org/10.1016/j.learninstruc.2007.01.008

Prosser, M., Martin, E., Trigwell, K., Ramsden, P., \& Middleton, H. (2008). University academics' experience of research and its relationship to their experience of teaching. Instructional Science, 36(1), 3-16. http://dx.doi.org/10.1007/s11251-007-9019-4

Remmik, M., \& Karm, M. (2013). From teaching to guiding learning: Novice university teachers' conceptions of teaching. In E. Saar \& R. Mõttus (Eds.), Higher Education at a crossroad: The case of Estonia (pp. 199-216). Frankfurt am Main: Peter Lang.

Reybold, L. E. (2005). Surrendering the dream. Early career conflict and faculty dissatisfaction thresholds. Journal of Career Development, 32(2), 107-121.

http://dx.doi.org/10.1177/0894845305279163 
Robertson, J., \& Bond, C. H. (2001). Experiences of the relation between teaching and research: What do academics value? Higher Education Research and Development, 20(1), 5-19. http://dx.doi.org/10.1080/07924360120043612

Rose, G. (2007). Visual methodologies: An introduction to the interpretation of visual material. London, Thousand Oaks, New Delhi: Sage Publications.

Ryan, G. W., \& Bernard, H. R. (2003). Techniques to identify themes. Field Methods, 15(1), 85-109. http://dx.doi.org/10.1177/1525822X02239569

Sadler, I. (2012). The influence of interactions with students for the development of new academics as teachers in higher education. Higher Education, 64(2), 147-160. http://dx.doi.org/10.1007/s10734-012-9545-0

Sherman, T. M., Armistead, L. P., Fowler, F., Barksdale, M. A., \& Reif, G. (1987). The quest for excellence in university teaching. Journal of Higher Education, 48(1), 66-84. http://dx.doi.org/10.2307/1981391

Taylor, E. W. (2002). Using still photography in making meaning of adult educators' teaching beliefs. Studies in the Education of Adults, 34(2), 123-139.

Trigwell, K., \& Prosser, M. (1996). Congruence between intention and strategy in university science teachers' approaches to teaching. Higher Education, 32(1), 77-87. http://dx.doi.org/10.1007/BF00139219

Van Driel, J. H., Verloop, N., van Werven, H. I., \& Dekkers, H. (1997). Teachers' craft knowledge and curriculum innovation in higher engineering education. Higher Education, 34(1), 105-122. http://dx.doi.org/10.1023/A:1003063317210

Vardi, I. (2011). The changing relationship between the scholarship of teaching (and learning) and universities. Higher Education Research and Development, 30(1), 1-7. http://dx.doi.org/10.1080/07294360.2011.536968

Warhurst, R. P. (2008). „Cigars on the flight-deck": New lecturers' participatory learning within workplace communities of practice. Studies in Higher Education, 33(4), 453-467. http://dx.doi.org/10.1080/03075070802211828

Weber, S., \& Mitchell, C. (1996). Drawing ourselves into teaching: Studying the images that shape and distort teacher education. Teaching and Teacher Education, 12(3), 303-313. http://dx.doi.org/10.1016/0742-051X(95)00040-Q

Whitchurch, C. (2012). Expanding parameters of academia. Higher Education, 64(1), 99-117. http://dx.doi.org/10.1007/s10734-011-9483-2

Woodley-Baker, R. (2009). Private and public experience captured: Young women capture their everyday lives and dreams through photo-narratives. Visual Studies, 24(1), 19-35. http://dx.doi.org/10.1080/14725860902732694 


\title{
Novice university teachers' teaching conceptions based on photo interviews
}

\author{
Mari Karm ${ }^{\text {al }}$, Marvi Remmik ${ }^{\mathrm{a}}$ \\ ${ }^{a}$ University of Tartu, Institute of Education
}

SUMMARY

\section{Theoretical framework}

The profession of a university teacher is gradually gaining more complexity. The main issues that academics identify as significant include the changing nature of their role concerning increased responsibilities, the challenge of being a quality teacher while producing assessable research outputs, role conflict, insufficient institutional support and continual organisational change (Billot, 2010). It is pertinent to achieve a balance between research work and teaching. Some staff acknowledge that they cannot undertake research as well as commit professionally to their field of practice and the effective teaching of students. This combination of responsibilities is time-consuming and teaching, administrative and research expectations may conflict with each other (Billot, 2010).

When discussing university teachers' work, their teaching conceptions should not be discarded. Research has demonstrated that university teachers' teaching conceptions have an impact on their teaching practice (Trigwell \& Prosser, 1996). By analysing different studies of university teachers' teaching conceptions, Kember (1997) finds that the conceptions could generally be placed under two broad orientations: teacher-centred, those that focus on the communication of defined bodies of content or knowledge, and studentcentred that focus on student learning. Postareff and Lindblom-Ylänne (2008) analyse descriptions of teaching by university teachers and find that most of the descriptions can be divided between content-centred and learningcentred conceptions.

In addition, some researchers (Åkerlind, 2004; van Driel, Verloop, van Werven, \& Dekkers, 1997) find that in between the teacher-centred and student-centred approach exists the teacher-student relations focused approach.

Institute of Education, Faculty of Social Sciences and Education, University of Tartu, Salme 1a, 50103 Tartu, Estonia, mari.karm@ut.ee 
In analyses about teaching conceptions, researchers have paid attention to what extent teaching conceptions are constant and to what extent they are changing, and what direction the changes are taking. Earlier studies (Kugel, 1993; Sherman, Armistead, Fowler, Barksdale, \& Reif, 1987) have demonstrated that at the beginning of their work, university teachers' teaching conceptions are more teaching-centred, and as teaching experience increases and as a result of training courses, the conceptions shift towards learning-centredness. At the same time, studies (Norton, Richardson, Hartley, Newstead, \& Mayes, 2005; Remmik \& Karm, 2013) indicate that novices can be placed at different locations on the teaching centred-learning centred axis, and depending on different factors (personal experience, training courses, community traditions, student feedback), changes can shift towards teaching or learning centredness. A university teacher's teaching conceptions are also impacted by how he/she sees his/her development as a university teacher. Studies by McAlpine and Weston (2000), Åkerlind (2003) and Postareff and Lindblom-Ylänne (2008) show that teaching conceptions play an important part in the extent to which university teachers are willing to develop their teaching at all, and which changes they are willing to make in their teaching practice. For instance, a university teacher with a teaching-centred conception focuses more on the subject's content when developing his/her teaching, while a university teacher with a learning-centred conception develops himself/herself in order to find ways to support student learning (e.g. feedback collection and analysis).

Changes in universities and in university teacher's activities mean that beginning university teachers are already expected to cope with several different tasks early in their career, including teaching. Therefore, it is important to study and understand how novice university teachers conceptualise their activities at the university, which learning conceptions their activities are based on, whether they develop themselves as university teachers and how.

Based on the aim of the research, the following research questions were formulated:

1. How do novice university teachers describe their work at university?

2. How do novice university teachers describe their teaching conceptions?

3. How do novice university teachers see their development as a university teacher? 


\section{Method}

Previous research has shown that it is complicated to investigate the ideals, concepts, beliefs and values of individuals, since people are not often aware of the concepts their professional practice is based on. Using visual research methods has given good results when investigating the underlying concepts (Taylor, 2002; Weber \& Mitchell, 1996; Woodley-Baker, 2009). Photographic interviews provide richer data than simple verbal interviews as photographs focus on and guide the process of the interview. Photographs also provide the impetus for interviewees to conceive and verbalize their understandings. The photographic elicitation interview process does not only elicit more information, but rather evokes a different kind of information (Harper, 2002; Rose, 2007).

\section{Process of the study}

Photographic interviews were used as the research method for studying the formation of teaching conceptions among novice university teachers. During the first stage of the study, life history interviews were conducted with the participants. The next step involved a photographic interview with 13 of the participants. The participants were requested to find photographs that illustrated answers to questions on learning, teaching and the image of a university teacher (e.g. What is your vision of teaching? What is a university teacher?). The participants were requested to take photographs, they were allowed to draw images if they preferred or select photographs from their own albums.

Indirect analysis was used in the interpretation of the photographs: the interviewees themselves selected and interpreted the photographs they had brought along. All the interviews were recorded and fully transcribed. The next stage involved analysing the interpretations and explanations offered by the interviewees, but the photographs themselves as independent material were not analysed. The interviews were analysed by making use of thematic analysis.

\section{Results}

Novice university teachers as a group should not be treated in a general manner since they are individually and intrinsically different in how they approach research work and teaching. Their teaching conceptions and willingness to change, develop and improve differ. 
The university teachers interviewed discuss the relations of research work and teaching. Some clearly emphasise teaching as being most important for them. Some highlight the understanding that doing research is most appealing in working at a university and that doing research forms the basis of a teacher's professional character as well as making teaching more stimulating.

The conception of teaching among novice university teachers can be teaching-centred or learning-centred. The study confirmed the findings of earlier studies, showing that novice university teachers can have a learningcentred approach, but they might have difficulties in implementing it in practice (Mälkki \& Lindblom-Ylänne, 2012), since they lack the necessary skills, work techniques, teaching methods or suitable environment (support from colleagues).

The vision of oneself as a university teacher in the future is based on ones present identity, activities and understandings on the one hand, while this image is affected by the dominant norms and ideals in a university, on the other hand. It is imagined that in the future, one will advance to become a subject expert, and the increased amount of knowledge and experience guarantees more influence. In these discussions and images, the tradition of a university becomes clear, namely, the norm that requires everyone in a university to be an expert sharing knowledge with students in a teachingcentred approach. The classical traditional teaching-centred conception comes to the fore among novice university teachers who are rather learningcentred in their present activities.

Among novice university teachers, there are also some who have very clear and traditional perceptions of teaching: a university has to provide an academic education, which is also a means to academic lecture-based teaching methods.

The further development of a novice university teacher has multiple directions, namely, a novice university teacher may become more teachingcentred due to tiredness, student opposition or the pressure of university traditions. Nevertheless, a novice university teacher may become more learning-centred once the necessary skills, teaching methods or a supportive environment (support from colleagues) have been obtained.

The following patterns could be outlined based on an analysis of photographic interviews:

1. Traditional university teachers. The representatives of this group do not contemplate much about teaching. Teaching is performed without doubt in the traditional manner and no intentions of further professional development are elicited. 
2. Doubtful and searching university teachers. The representatives of this group contemplate the identity of a university lecturer and teaching but are not certain of their teaching methods. They may be learning-centred at present but at the same time doubt whether this is the most suitable way of teaching at a university. They also have doubts about matching their present identity and future images.

3. Confident university teachers. The representatives of this group contemplate teaching, they have undergone changes and feel they have found a way of working and teaching in a university which they intend to continue and improve.

The further development of novice university teachers depends of their own agendas, conceptions and environment.

Photographs appeared to be a useful tool for both researchers and novice teachers. The researchers received an opportunity to obtain a glimpse of the unconscious thoughts of novice teachers about teaching, but they also helped the interviewees to view their professional self and their values in teaching.

The use of photographic interviews provided an opportunity to get together with the respondent repeatedly, and therefore, created closer contact and was a prerequisite for greater participant openness. It also gave researchers an opportunity to specify the themes covered in the first interview. The use of photographic interviews in the research meant that respondents were more deeply involved in the research: searching for or taking the photographs led the respondents to think about the questions more thoroughly. At the same time, some opted out of participating in the interview precisely because it seemed time and energy consuming for them. In addition, some participants saw the photographic interview as a research method that seemed unconvincing, and they did not want to get involved in questionable research. Therefore, the sample may be biased, as it is made up of the university teachers for whom visual methods were suitable.

Keywords: novice university teacher, teaching concepts, photographic interview, higher education 